\title{
Arthroscopic partial repair for massive rotator cuff tears: does it work? A systematic review
}

\author{
Michael-Alexander Malahias ${ }^{1 *}$, Lazaros Kostretzis², Efstathios Chronopoulos ${ }^{3}$, Emmanouil Brilakis ${ }^{1}$, \\ Grigorios Avramidis ${ }^{1}$ and Emmanouil Antonogiannakis ${ }^{1}$
}

\begin{abstract}
Background: While arthroscopic complete repair of massive rotator cuff tears (MRCT) back to their anatomic footprint is preferential, there are cases where this type of repair is not applicable due to the contraction of the torn tendons. In such cases, a non-anatomic incomplete or partial repair can be performed. A number of clinical studies have investigated the clinical and functional outcomes of arthroscopic partial repair for irreparable MRCT. To our knowledge, no systematic review has been published yet to synthetically evaluate these results.

Methods: Two reviewers independently conducted the search in a PRISMA-compliant systematic way using the MEDLINE/PubMed database and the Cochrane Database of Systematic Reviews. These databases were queried with the terms "arthroscopy"[MeSH Terms] OR arthroscopic surgical procedure [Text Word (tw)] AND massive rotator cuff tears [tw] AND arthroscopic partial repair [tw].

Results: From the 55 initial studies, we finally chose 11 clinical studies which were eligible to our inclusionexclusion criteria. The mean modified methodology Coleman score was 58/100, whereas it ranged from 41/100 to 78/100. In total, 643 patients were included in this review. All postoperative mean clinical and functional subjective scores, as well as muscle strength of patients treated with arthroscopic partial repair, were found significantly improved, when compared with the respective mean preoperative values. The rate of structural failure of the partial repair, as it was estimated by postoperative imaging modalities, was $48.9 \%$. The overall reoperations' rate was $2.9 \%$ regarding the patients who were treated with partial repair.
\end{abstract}

Conclusions: Arthroscopic partial repair might be a safe and effective alternative treatment for irreparable contracted MRCT, where a complete repair cannot be performed. The methodological quality of the relevant, available literature is low to moderate; therefore, further studies of higher quality are required to confirm these results.

Keywords: Shoulder arthroscopy, Arthroscopic partial repair, Medialized repair, Massive rotator cuff tear, Systematic review

\footnotetext{
* Correspondence: alexandermalahias@yahoo.gr

13rd Orthopaedic Department, Hygeia Hospital, Erythrou Stavrou 4, 15123

Marousi, Athens, Greece

Full list of author information is available at the end of the article
} 


\section{Key Points}

- Arthroscopic partial repair might be a safe and effective salvage solution in cases where an arthroscopic complete repair of massive rotator cuff tears cannot be performed.

- The methodological quality of the relevant, available literature is low to moderate; therefore, further studies of higher quality are required to confirm our results.

\section{Background}

The understanding of rotator cuff pathology and healing continues to evolve, beginning with emerging descriptions of the anatomic footprint and natural history of rotator cuff tears [1]. Shoulder anatomy, pathology, and biomechanics place unique stress on the rotator cuff tendons during sports activity [2], whereas smoking, hypercholesterolemia, and genetics have all been shown to influence the development of rotator cuff tearing [3].

Depending on the degree of cuff pathology, acromioplasty, debridement of partial cuff tears, and repair of full-thickness tears are usually successful in those who fail a rehabilitation program [4]. Complete repair, if possible, is the optimal treatment for full-thickness rotator cuff tears [5]. On the other hand, the management of massive, irreparable rotator cuff tears (MRCT) is challenging and associated with high failure rates, since there are no current consensus or definitive guidelines concerning the optimal surgical treatment for this devastating condition [6]. Arthroscopic options include rotator cuff repair, partial cuff repairs, tendon allografts or xenografts, decompression, débridement, biceps tenotomy, tenodesis, and tendon transfers [7]. The treatment modality specifically chosen for the massive, irreparable rotator cuff tear must be tailored to the individual patient, their needs and expectations, and their ability to comply with intensive rehabilitation [8].

While arthroscopic complete repair of MRCT back to their anatomic footprint is preferential, there are cases where this type of repair is not applicable due to the contraction of the torn tendons. In such cases, a non-anatomic incomplete or partial repair can be performed. Arthroscopic partial repair is indicated for young patients when the muscle is still trophic with a fatty infiltration less than 3 , according to the MRI-based Fuchs classification [9]. It can be combined with a tendon transfer like latissimus dorsi (or alternatively lower trapezius) in irreparable posterosuperior tears or pectoralis major (or alternatively latissimus dorsi) in anterosuperior cuff tears [10].

A number of clinical studies have investigated the clinical and functional outcomes of arthroscopic partial repair for irreparable MRCT [11-21]. To our knowledge, no systematic review has been published yet to synthetically evaluate these results.

Our aims were twofold: (1) to summarize failure rates and clinical/functional/radiographic outcomes associated with the arthroscopic partial repair as the method of treatment for symptomatic irreparable MRCT and (2) to characterize the methodological quality of the relevant, available literature. Our hypothesis was that arthroscopic partial repair would be proven a safe and effective treatment for this type of lesions where no complete repair can be done.

\section{Materials and methods}

Two reviewers (MAM, LK) independently conducted the search in a systematic way according to the Preferred Reporting Items for Systematic Reviews and Meta-Analyses (PRISMA) using the MEDLINE/PubMed database and the Cochrane Database of Systematic Reviews. These databases were searched using the terms "arthroscopy" [MeSH Terms] OR arthroscopic surgical procedure [Text Word (tw)] AND massive rotator cuff tears [tw] AND arthroscopic partial repair [tw]. To maximize the search, backward chaining of reference lists from retrieved papers was also undertaken. A preliminary assessment of only the titles and abstracts of the search results was initially performed. The second stage involved a careful review of the full-text publications.

Inclusion criteria were clinical studies investigating adult patients, diagnosed with symptomatic MRCT, who were treated with arthroscopic partial repair, and who had a minimum of 12 months clinical follow-up (with clinical tests and/or scores). These studies should have been written in English or German as full-text articles and they should have been published by March 1, 2018 (end of our search).

We excluded from our review all studies which were not dealing with partial repair (other means of operative or nonoperative treatment), non-arthroscopic procedures (open or mini-open), studies about reparable massive or non-massive RCT, trials with follow-up less than 12 months, studies without clinical/functional outcome variables, abstracts, editorial comments, case reports, corrigenda, technical notes, literature reviews, preclinical studies, and papers not written in English or German.

Differences between reviewers were discussed until agreement was achieved. In cases of disagreement, the senior author (EA) had the final decision. The two reviewers independently extracted data from each study and assessed variable reporting of outcome data. Descriptive statistics were calculated for each study and parameters analyzed. The "quality assessment" of the studies for methodological deficiencies, as a common 
alternative to "risk of bias" [22], was examined by the modified Coleman methodology score [23]. The methodological quality of each study and the different types of detected bias were assessed independently by each reviewer and then they were combined synthetically. Selective reporting bias like publication bias was not included in the assessment. The primary outcome measure was the failure rate leading to reoperation and the clinical, functional, and radiographic outcomes. The secondary outcome was the quality assessment of the studies with the use of the modified Coleman methodology score.

\section{Results}

From the 55 initial studies, we finally chose and assessed 11 clinical studies which were eligible to our inclusion-exclusion criteria [11-21]. We excluded all the irrelevant studies (16), technical notes (6), trials not referring to massive rotator cuff tears (5), reviews of the literature (4) (not relevant to our review), papers concerning only full repair (4), mini-open procedures (2), studies dealing with massive rotator cuff tears treated with subacromial biodegradable spacers (2) or greater tuberoplasty (1), trials regarding pigmented villonodular synovitis (1), case reports (1), papers without any clinical outcome (1), and papers written in Chinese (1). A summary flowchart of our literature search according to PRISMA guidelines can be found in Fig. 1.

\section{Level of evidence and study's design}

All studies included in this review were published between 2010 and 2016 [11-21] (Table 1).

Six out of the 11 studies of this review (54.5\%) had a level of evidence III [13-17, 19], while three studies (27.3\%) had a level of evidence IV [12, 18, 21], one study (9.1\%) a level of evidence I [11], and another one (9.1\%) a level of evidence II [20] (Table 2).

We found eight comparative studies $(72.7 \%)$ [11, 13$17,19,20]$ and three non-comparative studies (27.3\%) $[12,18,21]$, whereas only one trial (9.1\%) [11] was randomized and ten trials (90.9\%) were non-randomized [12-20]. The most common comparisons were between arthroscopic complete repair and partial repair [1417] as well as arthroscopic partial repair and debridement $[11,13,15]$. One study compared the arthroscopic partial repair technique with latissimus dorsi transfer [20] and another one with a patch autograft procedure [19] (Table 1).

\section{Quality of the studies and possible risk of bias}

The mean modified methodology Coleman score for methodological deficiencies of the studies was $58 / 100$, whereas it ranged from $41 / 100$ [16] to $78 / 100$ [11] (Table 2).
All studies of this review (100\%) were characterized by a possible high risk of performance bias [11-21], while nine studies $(81.8 \%)$ were found with possible selection bias [11, 13-17, 19-21], six studies (54.5\%) with possible detection bias [11-13, 16, 19, 20], and five studies $(45.5 \%)$ with possible attrition bias $[12,14,17-19]$ (Table 2).

\section{Demographics}

Totally, 643 patients were included in this review. From them, 348 patients were treated with an arthroscopic partial repair procedure, while 295 patients underwent another type of treatment (either as control or as study groups). The majority of the patients who were treated with the arthroscopic partial repair technique were males (63.7\%). The mean age of the patients who underwent arthroscopic partial repair ranged from 59.4 years [14] to 68 years [15], while the mean age of the patients who were treated with other operative techniques ranged from 62.5 years [20] to 66.5 years [15]. The mean follow-up of the patients who underwent arthroscopic partial repair ranged between 16 [11] and 93.6 months [13], whereas the mean follow-up of the patients who were treated with other operative techniques ranged from 24 months [11, 16, 17] to 93.6 months [13] (Table 3).

\section{Reoperation rate}

The overall reoperation rate was $2.9 \%$ for patients who were treated with partial repair. The most common reason for reoperation was severe glenohumeral osteoarthritis $(1.1 \%)$ and the second most common reason was failure of the repair and persistent pain (0.9\%). The most common type of reoperation was reverse shoulder arthroplasty (1.1\%) (Table 4).

\section{Clinical and functional outcome variables}

Range of motion (ROM) was measured in eight studies $(72.7 \%)$ [11-13, 15, 16, 19-21], muscle strength in six studies $(54.5 \%)[11,14,16,19-21]$, and patients' satisfaction in two studies $(18.2 \%)[15,21]$. The Constant score was used in six (54.5\%) of the studies which were included in this review [11, 14-16, 18, 19], whereas the visual analogue scale (VAS) in five studies (45.5\%) [12, 15, 19-21] as well as The University of California at Los Angeles (UCLA) Shoulder Score $(45.5 \%)[13,17-20]$. From the rest of the outcome variables, the most commonly used was the American Shoulder and Elbow Surgeons (ASES) score, with a $36.4 \%$ rate amongst studies [12, 16, 19, 21], whereas the Disabilities of the Arm, Shoulder and Hand (DASH) Score, subjective shoulder value (SSV), simple shoulder test (SST), and Rotator Cuff Quality of Life (RC-QOL) score were utilized equally in 18.2\% 


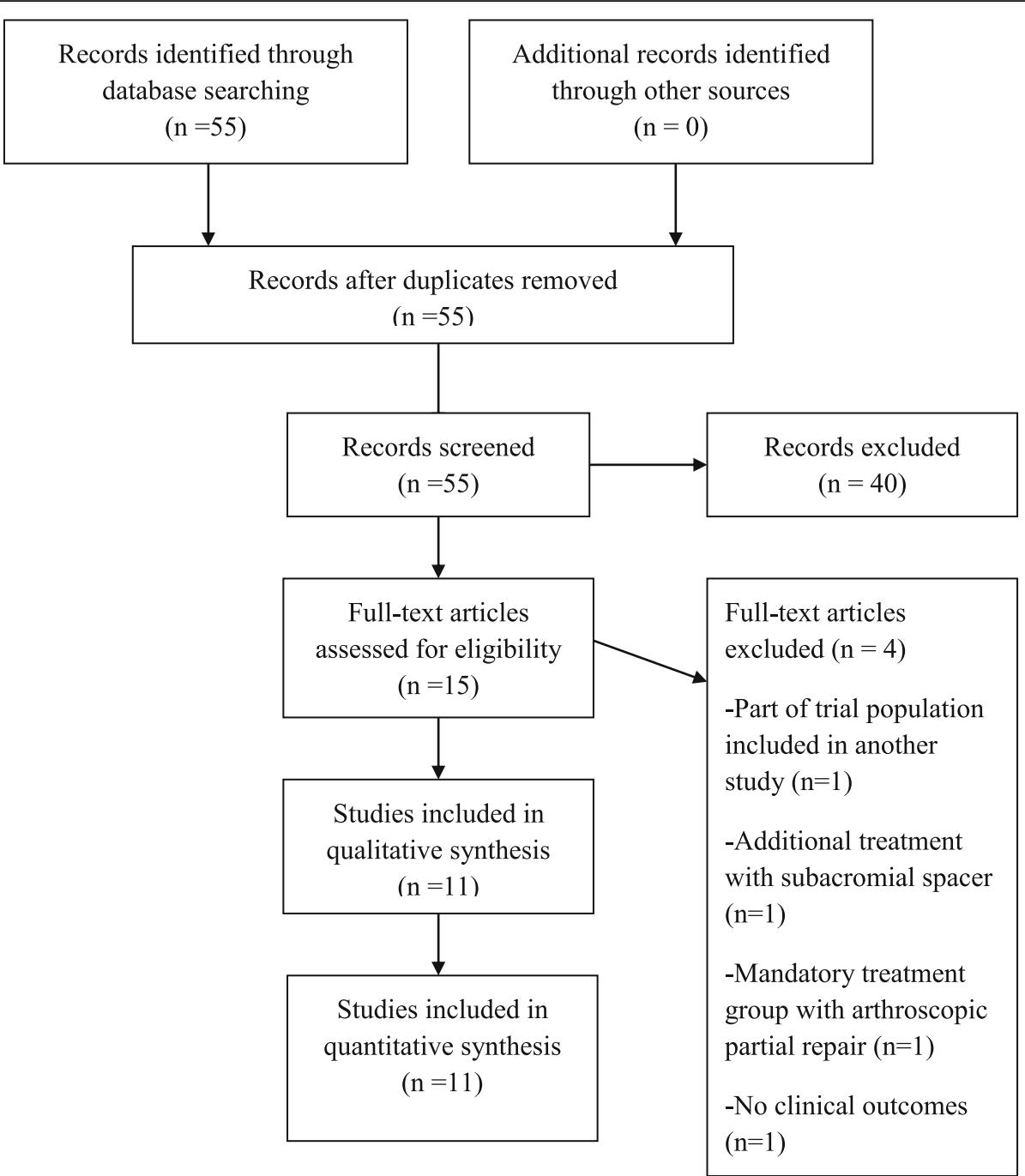

Fig. 1 Flow chart of study selection according to PRISMA guidelines for reporting systematic reviews and meta-analyses

$[11,15], 18.2 \%[14,15], 18.2 \%[12,21]$, and $18.2 \%$ $[13,20]$, respectively. Finally, the short Western Ontario Rotator Cuff Index was used in one study (9.1\%) [16] (Table 3).

All postoperative mean clinical and functional subjective scores, as well as muscle strength of patients treated with arthroscopic partial repair, were found significantly improved, when compared with the respective mean preoperative values in all 11 studies which were included in this review [11-21]. Ten out of 11 studies (90.9\%) documented significant postoperative improvement in the ROM of the arthroscopic partial repair-treated patients $[11,13-21]$, while one study (9.1\%) [12] did not illustrate any significant improvement in comparison with the preoperative ROM. In the two studies which evaluated patients' satisfaction, Heuberer et al. illustrated high postoperative patients' satisfaction (86\%) with the use of partial repair (no significant difference in comparison with the complete repair group as well as the debridement group), whereas Shon et al. showed that only half of the treated patients declared themselves satisfied [15, 21]. The specific preoperative and postoperative mean values of the clinical and functional outcome variables per study can be found in Table 4 .

\section{Repair integrity}

Four studies of this review (36.4\%) assessed the postoperative re-tear rate of the partial repair [11, 14, 15, 19]. Three of these studies (28.2\% of all studies) used diagnostic ultrasonography for their postoperative imaging evaluation $[11,14,15]$, while two studies $(18.2 \%)$ made use of the MRI $[15,19]$. Overall, the rate of structural failure of the partial repair was $48.9 \%$ amongst these studies $[11,14,15,19]$. 
Table 1 Year of study, design, and type of surgery for studies included in the review

\begin{tabular}{|c|c|c|c|}
\hline Study & Year & $\begin{array}{l}\text { Prospective/retrospective } \\
\text { design }\end{array}$ & Type of surgery \\
\hline Berth et al. [11] & 2010 & Prospective & Arthroscopic partial repair vs arthroscopic debridement \\
\hline Cuff et al. [12] & 2016 & Retrospective & Arthroscopic biceps tenotomy and partial repair \\
\hline $\begin{array}{l}\text { Francheschi et al. } \\
{[13]}\end{array}$ & 2012 & Prospective & Arthroscopic debridement vs arthroscopic partial repair \\
\hline $\begin{array}{l}\text { Godenèche et al. } \\
{[14]}\end{array}$ & 2016 & Prospective & Arthroscopic complete repair vs arthroscopic partial repair \\
\hline Heuberer et al. [15] & 2015 & Prospective & $\begin{array}{l}\text { Arthroscopic debridement vs arthroscopic partial repair vs arthroscopic complete } \\
\text { repair }\end{array}$ \\
\hline Holtby et al. [16] & 2014 & Retrospective & Arthroscopic complete repair vs arthroscopic partial repair \\
\hline lagulli et al. [17] & 2012 & Retrospective & Arthroscopic complete repair vs arthroscopic partial repair \\
\hline Kim et al. [18] & 2012 & Retrospective & Arthroscopic partial repair \\
\hline Mori et al. [19] & 2013 & Retrospective & Arthroscopic patch graft procedure vs arthroscopic partial repair \\
\hline Paribelli et al. [20] & 2015 & Prospective & Arthroscopic-assisted latissimus dorsi tendon transfer vs arthroscopic partial repair \\
\hline Shon et al. [21] & 2015 & Retrospective & Arthroscopic partial repair \\
\hline
\end{tabular}

\section{Radiographic outcomes}

Two studies $(18.2 \%)[12,21]$ reported the postoperative radiographic progression of osteoarthritis according to Hamada score [24]. According to Shon et al., all patients included in their study were found without any changes in the Hamada score at their final follow-up X-ray when it was compared with the initial preoperative score [21]. On the contrary, $36 \%$ of the patients (10 out of 28 patients) who were followed in the study of Cuff et al. had postoperative osteoarthritic progression of one or more Hamada stages [12] (Table 3).

Kim et al. found a small but statistically significant postoperative decrease in the acromiohumeral distance in comparison with the mean preoperative value (from a preoperative mean value of $6.5 \mathrm{~mm}$ to a postoperative mean value of $5.9 \mathrm{~mm} ; p<0.001$ ) [18]. However, according to Kim et al., this difference was not clinically significant [18] (Table 3).

\section{Discussion}

The most important finding of this review was that all those studies which evaluated arthroscopic partial repair for the treatment of irreparable MRCT documented significant improvements in all postoperative subjective clinical and functional scores which were measured. All studies showed significant improvement of postoperative muscle strength and almost all of them reported significant improvement in the ROM at the last follow-up assessment. It seems that the rebalanced remaining anterior and posterior parts of the rotator cuff recover shoulder stability, which subsequently allows better function and decreased pain even after a partial non-anatomic repair [25].

In addition, the complication and reoperation rates in our review were found to be very low. Clinical symptoms like persistent pain due to failure of the repair were rather uncommon and only rarely led to a revision surgery. According to these results, arthroscopic partial

Table 2 Level of evidence, modified Coleman methodology score, and high risk of possible bias per study

\begin{tabular}{llll}
\hline Study & Study level & Modified Coleman score (0-100) & Risk of bias \\
\hline Berth et al. [11] & I & 78 & Selection, performance, detection \\
Cuff et al. [12] & IV & 56 & Performance, detection, attrition \\
Francheschi et al. [13] & III & 70 & Selection, performance, detection \\
Godenèche et al. [14] & III & 63 & Selection, performance, attrition \\
Heuberer et al. [15] & III & 59 & Selection, performance \\
Holtby et al. [16] & III & 41 & Selection, performance, detection \\
lagulli et al. [17] & III & 51 & Selection, performance, attrition \\
Kim et al. [18] & IV & 53 & Performance, attrition \\
Mori et al. [19] & III & 48 & Selection, performance, detection, attrition \\
Paribelli et al. [20] & II & 60 & Selection, performance, detection \\
Shon et al. [21] & IV & 59 & Selection, performance
\end{tabular}


Table 3 Number of shoulders per study, sex, mean age, mean follow-up, clinical/functional, and imaging outcome variables used

\begin{tabular}{|c|c|c|c|c|c|c|}
\hline Study & $\begin{array}{l}\text { Number of } \\
\text { shoulders }\end{array}$ & Sex (males/females) & Mean age (years) & $\begin{array}{l}\text { Mean follow-up } \\
\text { (months) }\end{array}$ & Clinical outcome scales & $\begin{array}{l}\text { Imaging outcome } \\
\text { evaluation }\end{array}$ \\
\hline Berth et al. [11] & $\begin{array}{l}42 \text { (partial: A, 21; } \\
\text { debridement: B, 21) }\end{array}$ & $\begin{array}{l}\text { A, } 15 / 6 \\
B, 16 / 5\end{array}$ & $\begin{array}{l}A, 62.5 \pm 2.3 \\
B, 64.3 \pm 3.4\end{array}$ & $\begin{array}{l}A, 16 \pm 3 \\
B, 24 \pm 2\end{array}$ & $\begin{array}{l}\text { Constant score, } \\
\text { DASH score, ROM }\end{array}$ & Ultrasonography \\
\hline Cuff et al. [12] & 28 & $19 / 9$ & $65.2(60-90)$ & $71.1(60-90)$ & $\begin{array}{l}\text { ASES score, SST score, } \\
\text { VAS score, ROM }\end{array}$ & $\begin{array}{l}\text { Radiographic } \\
\text { (Hamada stage) }\end{array}$ \\
\hline $\begin{array}{l}\text { Francheschi et } \\
\text { al. [13] }\end{array}$ & $\begin{array}{l}68 \text { (debridement: } \\
\text { A, 34; partial: B, 34) }\end{array}$ & $\begin{array}{l}\text { A, } 22 / 12 \\
B, 25 / 9\end{array}$ & $62(47-76)$ & $93.6 \pm 27.6$ & $\begin{array}{l}\text { ROM, modified } \\
\text { UCLA, RC-QOL }\end{array}$ & Not evaluated \\
\hline $\begin{array}{l}\text { Godenèche et } \\
\text { al. [14] }\end{array}$ & $\begin{array}{l}73 \text { (complete: } A, \\
\text { 50; partial: } B, 23 \text { ) }\end{array}$ & $52 / 21$ & $59.4 \pm 8.8$ & $41(29-55)$ & $\begin{array}{l}\text { Constant score, } \\
\text { subjective } \\
\text { shoulder value, } \\
\text { strength }\end{array}$ & Ultrasonography \\
\hline $\begin{array}{l}\text { Heuberer } \\
\text { et al. [15] }\end{array}$ & $\begin{array}{l}68 \text { (debridement: } \\
\text { A, 23; partial: B, } \\
\text { 22, complete: C:23) }\end{array}$ & $\begin{array}{l}40 / 28(A, 11 / 12 ; B, 14 / \\
8 ; C, 15 / 8)\end{array}$ & $\begin{array}{l}66.5 \pm 7.2(A, 66.5 ; B \\
68 ; C, 65)\end{array}$ & 45 & $\begin{array}{l}\text { Constant score, } \\
\text { ROM, VAS, } \\
\text { subjective shoulder } \\
\text { value, qDASH, } \\
\text { satisfaction rate }\end{array}$ & MRI, ultrasonography \\
\hline $\begin{array}{l}\text { Holtby et al. } \\
{[16]}\end{array}$ & $\begin{array}{l}122 \text { (partial: A, 73; } \\
\text { complete: B, 49) }\end{array}$ & $\begin{array}{l}\text { A, 48/25 } \\
\text { B, 33/16 }\end{array}$ & $\begin{array}{l}\text { A, } 67 \pm 9 \\
B, 64 \pm 9\end{array}$ & 24 & $\begin{array}{l}\text { ASES score, relative } \\
\text { Constant-Murley score, } \\
\text { short western Ontario } \\
\text { rotator cuff index, } \\
\text { ROM, strength }\end{array}$ & Not evaluated \\
\hline $\begin{array}{l}\text { lagulli } \\
\text { et al. [17] }\end{array}$ & $\begin{array}{l}97 \text { (86 evaluated) } \\
\text { (partial: A, 45; } \\
\text { complete: } B, 52 \text { ) }\end{array}$ & Not reported & $\begin{array}{l}\text { A, } 64.5 \pm 9.5 \\
B, 63.4 \pm 12.2\end{array}$ & $24(10-40)$ & UCLA score & Not evaluated \\
\hline Kim et al. [18] & 27 & Not reported & $62.3(54-72)$ & $41.3(36-52)$ & $\begin{array}{l}\text { UCLA score, Constant } \\
\text { score, ROM, strength }\end{array}$ & $\begin{array}{l}\text { Radiographic } \\
\text { (acromiohumeral distance) }\end{array}$ \\
\hline Mori et al. [19] & $\begin{array}{l}48 \text { (patch: } A_{1} \\
\text { 24; partial: } B, 24)\end{array}$ & $\begin{array}{l}\text { A, } 17 / 7 \\
B, 10 / 14\end{array}$ & $\begin{array}{l}A, 65.9 \pm 8.9 \\
B, 65.4 \pm 9.2\end{array}$ & $\begin{array}{l}\text { A, } 35.5 \pm 8.6 \\
\text { B, } 35.7 \pm 7.0\end{array}$ & $\begin{array}{l}\text { Constant score, } \\
\text { ASES score, } \\
\text { UCLA score, } \\
\text { VAS score, } \\
\text { ROM, strength }\end{array}$ & MRI \\
\hline $\begin{array}{l}\text { Paribelli } \\
\text { et al. [20] }\end{array}$ & $\begin{array}{l}40 \text { (tendon transfer: } \\
\text { A, 20; partial } \\
\text { repair: } B, 20 \text { ) }\end{array}$ & $\begin{array}{l}\mathrm{A}, 13 / 7 \\
\mathrm{~B}, 11 / 9\end{array}$ & $\begin{array}{l}\text { A, } 62.5(45-77) \\
\text { B, } 64.9(47-78)\end{array}$ & $33.6(12-60)$ & $\begin{array}{l}\text { Modified UCLA } \\
\text { score, ROM, } \\
\text { RC-QOL,VAS } \\
\text { score, strength }\end{array}$ & Not evaluated \\
\hline Shon et al. [21] & 31 & $17 / 14$ & $65.9 \pm 6.5$ & $40 \pm 14.9$ & $\begin{array}{l}\text { VAS-pain score, } \\
\text { ASES score, } \\
\text { simple shoulder } \\
\text { test score, patients' satisfaction }\end{array}$ & $\begin{array}{l}\text { Radiographic } \\
\text { (Hamada classification) }\end{array}$ \\
\hline
\end{tabular}

repair can be chosen as a safe and effective salvage solution in cases where an arthroscopic complete repair cannot be performed. This means that arthroscopic partial repair does not substitute complete anatomic repair, which remains the treatment of choice in cases where the retracted torn tendons can be repaired back to their anatomic footprint.

On the other hand, the re-tear rate of the repair, as estimated by postoperative MRI or ultrasound, was found to be almost $50 \%$. This very high rate of structural failure of the arthroscopic partial repair raises serious concerns regarding the actual value of this treatment. Notwithstanding, the clinical relevance of this finding remains controversial as many patients continue to improve, not only clinically but also functionally (ROM and strength), even when the integrity of the repair has deteriorated. According to Lubiatowski et al., rotator cuff integrity after arthroscopic repair does not seem to affect clinical scores [26]. A possible explanation might be that the reduction of pain-related muscle activity inhibition via arthroscopic debridement, lavage, and intra-articular synovectomy could lead to increased shoulder muscle strength regardless of the success of the repair [11, 27]. Moreover, a possible complete or partial decompression of a tethered suprascapular nerve during the arthroscopic procedure might also contribute to the symptomatic relief of the patient, independently of the longevity of the repair [28].

Kim et al. illustrated that there was a significant decrease in the acromiohumeral distance after surgery [18]. Nevertheless, the importance of this X-ray finding in relation to a possible development of rotator cuff arthropathy has yet to be determined in future studies. While Kim et al. reported no osteoarthritic changes (Hamada score) in any of their patients [18], Shon et al. showed that more than one third of their patients had deteriorated radiographic outcomes [21]. Long-term studies are considered necessary to show whether 
Table 4 Preoperative and postoperative clinical and functional mean scores per study, complications, and take-home message

\begin{tabular}{|c|c|c|c|c|}
\hline Study & $\begin{array}{l}\text { Preoperative } \\
\text { scores }\end{array}$ & Postoperative scores & Complications & Take-home message \\
\hline \multirow[t]{2}{*}{ Berth et al. [11] } & $\begin{array}{l}\text { A: Constant } 36.9 \\
\text { DASH } 64.6 \\
\text { ROM Abd } 97.7^{\circ} \\
\text { Add } 28^{\circ} \\
\text { IR } 67.5^{\circ} \\
\text { ER } 41.7^{\circ}\end{array}$ & $\begin{array}{l}\text { A: Constant } 58.2 \\
\text { DASH } 23.8 \\
\text { ROM Abd } 144^{\circ} \\
\text { Add } 37.2^{\circ} \\
\text { IR } 79.5^{\circ} \\
\text { ER } 47^{\circ}\end{array}$ & $\begin{array}{l}\text { A: } 1 \text { patient with } \\
\text { persistent pain } \\
\text { was reoperated } \\
\text { arthroscopic debridement) }\end{array}$ & \multirow[t]{2}{*}{$\begin{array}{l}\text { In cases of massive rotator } \\
\text { cuff rupture, early and } \\
\text { mid-term results of partial } \\
\text { repair were slightly superior } \\
\text { to those of arthroscopic } \\
\text { debridement alone. }\end{array}$} \\
\hline & $\begin{array}{l}\text { B: Constant } 29.9 \\
\text { DASH } 69.5 \\
\text { ROM Abd } 93.5^{\circ} \\
\text { Add } 28^{\circ} \\
\text { IR } 49.5^{\circ} \\
\text { ER } 40.5^{\circ}\end{array}$ & $\begin{array}{l}\text { B: Constant } 40.7 \\
\text { DASH } 35.3 \\
\text { ROM Abd } 103.5^{\circ} \\
\text { Add } 35.2^{\circ} \\
\text { IR } 71.6^{\circ} \\
\text { ER } 42.7^{\circ}\end{array}$ & $\begin{array}{l}\text { B: } 1 \text { patient developed } \\
\text { severe glenohumeral } \\
\text { arthritis and was } \\
\text { treated with shoulder } \\
\text { hemiarthroplasty }\end{array}$ & \\
\hline Cuff et al. [12] & $\begin{array}{l}\text { ASES } 46.6 \\
\text { SST } 5.6 \\
\text { VAS } 6.9 \\
\text { ROM FF } 168^{\circ} \\
\text { ER } 38^{\circ} \\
\text { IR } 84 \% \text { full IR }\end{array}$ & $\begin{array}{l}\text { ASES } 79.3 \\
\text { SST } 9.1 \\
\text { VAS } 1.9 \\
\text { ROM FF } 154^{\circ} \\
\text { ER } 39^{\circ} \\
\text { IR } 80 \% \text { full IR }\end{array}$ & $\begin{array}{l}3 \text { patients elected for } \\
\text { revision to reverse } \\
\text { shoulder arthroplasty }\end{array}$ & $\begin{array}{l}\text { The treatment of massive } \\
\text { rotator cuff tears with partial } \\
\text { arthroscopic rotator cuff } \\
\text { repair and biceps tenotomy } \\
\text { results in midterm subjective } \\
\text { satisfaction in the } \\
\text { majority of patients. }\end{array}$ \\
\hline \multirow[t]{2}{*}{$\begin{array}{l}\text { Francheschi et al. } \\
\text { [13] }\end{array}$} & $\begin{array}{l}\text { A: Mod UCLA } 7.6 \\
\text { VAS } 6.7 \\
\text { RC-QOL N.A. } \\
\text { ROM ER } 42.9^{\circ} \\
\text { IR } 37.8^{\circ} \\
\text { FF } 104.1^{\circ}\end{array}$ & $\begin{array}{l}\text { A: Mod UCLA } 21.4 \\
\text { VAS } 1.5 \\
\text { RC-QOL } 61.8 \\
\text { ROM ER } 42.9^{\circ} \\
\text { IR } 37.8^{\circ} \\
\text { FF } 104.1^{\circ}\end{array}$ & \multirow[t]{2}{*}{ Not reported } & \multirow{2}{*}{$\begin{array}{l}\text { In the surgical treatment } \\
\text { of irreparable rotator } \\
\text { cuff tears, arthroscopic } \\
\text { debridement associated } \\
\text { Iwith acromioplasty and } \\
\text { bursectomy and partial } \\
\text { repair of rotator cuff tear } \\
\text { are both effective in reducing } \\
\text { symptoms, with the latter } \\
\text { also offering higher } \\
\text { functional outcomes. }\end{array}$} \\
\hline & $\begin{array}{l}\text { B: Mod UCLA } 8.6 \\
\text { VAS } 6.8 \\
\text { RC-QOL N.A. } \\
\text { ROM ER } 40.6^{\circ} \\
\text { IR } 40^{\circ} \\
\text { FF } 111.5^{\circ}\end{array}$ & $\begin{array}{l}\text { B: Mod UCLA } 28.8 \\
\text { VAS } 1.8 \\
\text { RC-QOL } 71.2 \\
\text { ROM ER } 50.5^{\circ} \\
\text { IR } 68.7^{\circ} \\
\text { FF } 163.5^{\circ}\end{array}$ & & \\
\hline \multirow[t]{2}{*}{ Godenèche et al. [14] } & $\begin{array}{l}\text { A: Constant } 30.8 \\
\text { Strength } 1.1 \mathrm{~kg} \\
\text { SSV N.A. }\end{array}$ & $\begin{array}{l}\text { A: Constant } 79.7 \\
\text { Strength } 5.3 \mathrm{~kg} \\
\text { SSV } 79.2\end{array}$ & \multirow[t]{2}{*}{ Not reported } & \multirow{2}{*}{$\begin{array}{l}\text { The repair of massive rotator } \\
\text { cuff tears with partial or complete } \\
\text { repair results in equivalent } \\
\text { Constant scores improvement. }\end{array}$} \\
\hline & $\begin{array}{l}\text { B: Constant } 32.2 \\
\text { Strength } 1.5 \mathrm{~kg} \\
\text { SSV N.A. }\end{array}$ & $\begin{array}{l}\text { B: Constant } 75.3 \\
\text { Strength } 3.6 \mathrm{~kg} \\
\text { SSV } 70.2\end{array}$ & & \\
\hline \multirow[t]{3}{*}{ Heuberer et al. [15] } & \multirow[t]{3}{*}{ N/A } & $\begin{array}{l}\text { A: Constant: } 65.8 \\
\text { Q-DASH: } 24.1\end{array}$ & $\begin{array}{l}\text { A: } 1 \text { patient with revision } \\
\text { to reverse shoulder } \\
\text { arthroplasty due to pain }\end{array}$ & \multirow{3}{*}{$\begin{array}{l}\text { Arthroscopic debridement, } \\
\text { partial rotator cuff repair, } \\
\text { and complete rotator cuff } \\
\text { repair are effective in treating } \\
\text { massive rotator cuff tears. } \\
\text { Complete rotator cuff repair } \\
\text { shows better short-term results. }\end{array}$} \\
\hline & & $\begin{array}{l}\text { B: Constant: } 67.5 \\
\text { Q-DASH: } 20.5\end{array}$ & $\begin{array}{l}\text { B: } 2 \text { patients with } \\
\text { postoperative infections: } \\
\text { treated with arthroscopic } \\
\text { debridement and lavage, } \\
1 \text { patient with anchor } \\
\text { loosening: arthroscopic } \\
\text { anchor removal }\end{array}$ & \\
\hline & & $\begin{array}{l}\text { C: Constant: } 80.3 \\
\text { Q-DASH: } 7.0 \\
\text { Patients satisfied: A: 87\%, B: } 86 \%, \text { C: } \\
91 \%\end{array}$ & $\begin{array}{l}\text { C: } 1 \text { patient with re-tear } \\
\text { and revision to reverse } \\
\text { shoulder arthroplasty } \\
\text { and } 1 \text { patient with infection }\end{array}$ & \\
\hline \multirow[t]{2}{*}{ Holtby et al. [16] } & $\begin{array}{l}\text { A: ASES } 42.6 \\
\text { CMS } 44.0 \\
\text { ShortWORC } 34.6 \\
\text { ROM Flex } 110.1^{\circ} \\
\text { Abd } 102.7^{\circ} \\
\text { ER } 36.2^{\circ} \\
\text { Strength } 3.8\end{array}$ & $\begin{array}{l}\text { A: ASES } 71.4 \\
\text { CMS } 73.7 \\
\text { ShortWORC } 62.7 \\
\text { ROM Flex } 129.5^{\circ} \\
\text { Abd } 121.3^{\circ} \\
\text { ER } 42.8^{\circ} \\
\text { Strength } 5.9\end{array}$ & Not reported & \multirow{2}{*}{$\begin{array}{l}\text { The partial repair of massive } \\
\text { rotator cuff tears showed } \\
\text { a statistically significant } \\
\text { improvement in ROM, } \\
\text { strength and disability } \\
\text { scores. However, the } \\
\text { results were slightly } \\
\text { inferior compared } \\
\text { to complete repair. }\end{array}$} \\
\hline & $\begin{array}{l}\text { B: ASES } 51.0 \\
\text { CMS } 47.6 \\
\text { ShortWORC } 38.9\end{array}$ & $\begin{array}{l}\text { B: ASES } 82.8 \\
\text { CMS } 87.9 \\
\text { ShortWORC } 79.4\end{array}$ & & \\
\hline
\end{tabular}


Table 4 Preoperative and postoperative clinical and functional mean scores per study, complications, and take-home message (Continued)

\begin{tabular}{|c|c|c|c|c|}
\hline Study & $\begin{array}{l}\text { Preoperative } \\
\text { scores }\end{array}$ & Postoperative scores & Complications & Take-home message \\
\hline & $\begin{array}{l}\text { ROM Flex } 119.9^{\circ} \\
\text { Abd } 107.2^{\circ} \\
\text { ER } 44.4^{\circ} \\
\text { Strength } 4.8\end{array}$ & $\begin{array}{l}\text { ROM Flex } 153.4^{\circ} \\
\text { Abd } 142.5^{\circ} \\
\text { ER } 49.1^{\circ} \\
\text { Strength } 9.9\end{array}$ & & \\
\hline \multirow[t]{2}{*}{ lagulli et al. [17] } & A: UCLA 12.1 & A: UCLA 29.5 & $\begin{array}{l}\text { A: } 3 \text { patients underwent } \\
\text { revision partial repair }\end{array}$ & \multirow{2}{*}{$\begin{array}{l}\text { Partial repair of massive } \\
\text { rotator cuff tears yields } \\
\text { comparable short-term } \\
\text { results to complete repair. }\end{array}$} \\
\hline & B: UCLA 11.2 & B: UCLA 29.6 & $\begin{array}{l}\text { B: } 1 \text { patient sustained } \\
\text { traumatic retear and } \\
\text { underwent revision } \\
\text { complete repair }\end{array}$ & \\
\hline Kim et al. [18] & $\begin{array}{l}\text { Constant } 43.6 \\
\text { UCLA } 10.5\end{array}$ & $\begin{array}{l}\text { Constant } 74.1 \\
\text { UCLA } 25.9\end{array}$ & Not reported & $\begin{array}{l}\text { Arthroscopic partial repair } \\
\text { and margin convergence } \\
\text { showed satisfactory } \\
\text { short-term outcomes } \\
\text { in massive rotator cuff tears }\end{array}$ \\
\hline \multirow[t]{2}{*}{ Mori et al. [19] } & $\begin{array}{l}\text { A: Constant } 37.4 \\
\text { ASES } 40.8 \\
\text { UCLA } 14.3 \\
\text { VAS } 7.0 \\
\text { ROM FF } 114^{\circ} \\
\text { ER } 27.9^{\circ} \\
\text { IR } 17^{\circ}\end{array}$ & $\begin{array}{l}\text { A: Constant } 81.1 \\
\text { ASES } 94.1 \\
\text { UCLA } 32.6 \\
\text { VAS } 0.3 \\
\text { ROM FF } 160.8^{\circ} \\
\text { ER } 46^{\circ} \\
\text { IR } 11.6^{\circ}\end{array}$ & No complications & \multirow[t]{2}{*}{$\begin{array}{l}\text { In the arthroscopic treatment } \\
\text { of irreparable massive rotator } \\
\text { cuff tears with low-grade } \\
\text { fatty infiltration of infraspinatus, } \\
\text { the patch graft showed a lower } \\
\text { retear rate }(8.3 \%) \text { than } \\
\text { partial repair (41.7\%). }\end{array}$} \\
\hline & $\begin{array}{l}\text { B: Constant } 36.3 \\
\text { ASES } 41.8 \\
\text { UCLA } 13.7 \\
\text { VAS } 7.0 \\
\text { ROM FF } 110.6^{\circ} \\
\text { ER } 28.1^{\circ} \\
\text { IR } 17^{\circ}\end{array}$ & $\begin{array}{l}\text { B: Constant } 69.9 \\
\text { ASES } 85.7 \\
\text { UCLA } 29.8 \\
\text { VAS } 1.2 \\
\text { ROM FF } 162.3^{\circ} \\
\text { ER } 44.6^{\circ} \\
\text { IR } 11.6^{\circ}\end{array}$ & & \\
\hline \multirow[t]{2}{*}{ Paribelli et al. [20] } & $\begin{array}{l}\text { A: UCLA } 7.3 \\
\text { VAS } 6.9 \\
\text { RC-QOL n.a. } \\
\text { ROM FF } 83.5^{\circ} \\
\text { ER } 14.5^{\circ}\end{array}$ & $\begin{array}{l}\text { A: UCLA } 30.3 \\
\text { VAS } 1.3 \\
\text { RC-QOL } 81.8 \\
\text { ROM FF } 131^{\circ} \\
\text { ER } 41.2^{\circ}\end{array}$ & $\begin{array}{l}\text { A: A rupture of the } \\
\text { latissimus dorsi tendon } \\
\text { was recorded } 13 \text { months } \\
\text { postoperatively. A reverse } \\
\text { total shoulder } \\
\text { arthroplasty was performed. }\end{array}$ & \multirow{2}{*}{$\begin{array}{l}\text { In irreparable rotator cuff tears, } \\
\text { arthroscopic-assisted latissimus } \\
\text { dorsi tendon transfer and } \\
\text { arthroscopic rotator cuff } \\
\text { partial repair are both } \\
\text { effective ways to treat } \\
\text { patients' symptoms. In } \\
\text { younger patients, the first } \\
\text { option offers better } \\
\text { clinical results. }\end{array}$} \\
\hline & $\begin{array}{l}\text { B: UCLA } 7.6 \\
\text { VAS } 6.6 \\
\text { RC-QOL n.a. } \\
\text { ROM FF } 86.3^{\circ} \\
\text { ER } 15.8^{\circ}\end{array}$ & $\begin{array}{l}\text { B: UCLA } 20.1 \\
\text { VAS } 1.5 \\
\text { RC-QOL } 69.3 \\
\text { ROM FF } 110^{\circ} \\
\text { ER 38.4 }\end{array}$ & B: Not reported & \\
\hline Shon et al. [21] & $\begin{array}{l}\text { ASES } 41.97 \\
\text { SST } 3.61 \\
\text { VAS } 5.13 \\
\text { ROM FF } 132.9^{\circ} \\
\text { ER } 35.5^{\circ} \\
\text { IR } 10.6^{\circ}\end{array}$ & $\begin{array}{l}\text { ASES } 73.78 \\
\text { SST } 6.07 \\
\text { VAS } 3.16 \\
\text { ROM FF not reported } \\
\text { ER not reported } \\
\text { IR not reported }\end{array}$ & Not reported & $\begin{array}{l}\text { Arthroscopic partial repair of } \\
\text { irreparable massive rotator } \\
\text { cuff tears may produce } \\
\text { short-term improvement. } \\
\text { Fatty infiltration of the } \\
\text { teres minor was the } \\
\text { identified factor that } \\
\text { affected patient-rated satisfaction. }\end{array}$ \\
\hline
\end{tabular}

arthroscopic partial repair results in progression of glenohumeral osteoarthritis or not.

The total number of patients who were treated with arthroscopic partial repair was rather small to extract definite conclusions. In addition, the follow-up varied widely amongst studies, from 2 to 8 years, and no studies reported long-term follow-up. Considering that this is an operative procedure with only short- to mid-term results documented, new studies investigating the long-term outcome of arthroscopic partial repair are required to confirm the therapeutic value of this technique.

The overall quality of the studies was not high and was rated as moderate according to the mean modified Coleman methodology score. Most studies included were characterized by high risk of various potential bias, especially performance and selection bias. In addition, a relative lack of well-designed prospective trials was noted, since there was only one randomized controlled trial [11] and almost 
all other studies were of level III or IV. Other drawbacks were that some studies assessed heterogeneous populations with significantly different baseline characteristics amongst groups, including patients with different grades of fatty infiltration, size and types of lesions, and number and type of torn tendons. Finally, even the type of the operative procedure which was described as arthroscopic partial repair was not exactly the same. Some physicians performed a medialized repair that allowed for a tension-free repair [29], whereas some other authors used the typical partial repair with margin convergence as initially described by Burkhart et al. [30].

\section{Conclusions}

Arthroscopic partial repair might be a safe and effective alternative treatment for irreparable contracted MRCT, where a complete repair cannot be performed. The methodological quality of the relevant, available literature is low to moderate; therefore, further studies of higher quality are required to confirm these results.

\section{Abbreviations}

Abd: Abduction; Add: Adduction; CMS: Constant-Murley Score;

DASH: Disabilities of the Arm, Shoulder and Hand Score; ER: External rotation; FF: Forward flexion; IR: Internal rotation; MRCT: Massive rotator cuff tears; RCQOL: Rotator Cuff Quality of Life score; RCT: Rotator cuff tears; ROM: Range of motion; SST: Simple shoulder test; SSV: Subjective shoulder value; TW: Text Word; UCLA: University of California at Los Angeles Shoulder Score; VAS: Visual analogue scale; WORC: Western Ontario Rotator Cuff Index

\section{Acknowledgements}

None declared

\section{Funding}

No sources of funding were used to assist in the preparation of this review.

\section{Availability of data and materials}

Data sharing not applicable to this article as no datasets were generated or analysed during the current study.

\section{Authors' contributions \\ M-AM conducted the research protocol, assessed the data of the review independently from the other reviewers, and wrote the manuscript as the main author. LK gathered the data and assessed them independently from the other reviewers. EC critically revised and edited the manuscript. EB assisted in the interpretation of data and critical revision of the manuscript. GA critically revised the manuscript. EA supervised as the senior author of the whole project and revised critically and edited the manuscript. All authors read and approved the final manuscript.}

\section{Ethics approval}

Not applicable (Review Article without involving animals, human participants, human data or human tissue)

\section{Consent for publication}

Not applicable.

\section{Competing interests}

The authors, Michael-Alex, er Malahias, Lazaros Kostretzis, Efstathios Chronopoulos, Emmanouil Brilakis, Gregorios Avramidis, and Emmanouil Antonogiannakis, declare that they have no competing interests.

\section{Publisher's Note}

Springer Nature remains neutral with regard to jurisdictional claims in published maps and institutional affiliations.

\section{Author details}

13rd Orthopaedic Department, Hygeia Hospital, Erythrou Stavrou 4, 15123 Marousi, Athens, Greece. ${ }^{2}$ HKF Zentrum, ATOS Klinik, Heidelberg, Germany. ${ }^{3}$ 2nd Orthopaedic Department, School of Medicine, National and Kapodistrian University of Athens, Agias Olgas 3, 14233 Nea lonia, Athens, Greece.

Received: 7 November 2018 Accepted: 20 March 2019

Published online: 11 April 2019

\section{References}

1. Nathani A, Smith K, Wang T. Partial and full-thickness RCT: modern repair techniques. Curr Rev Musculoskelet Med. 2018;11(1):113-21. https://doi.org/ 10.1007/s12178-018-9465-4.

2. Plate JF, Haubruck P, Walters J, et al. Rotator cuff injuries in professional and recreational athletes. J Surg Orthop Adv. 2013:22(2):134-42 Summer.

3. Tashjian RZ. Epidemiology, natural history, and indications for treatment of rotator cuff tears. Clin Sports Med. 2012;31(4):589-604. https://doi.org/10. 1016/j.csm.2012.07.001 Epub 2012 Aug 30.

4. Blevins FT. Rotator cuff pathology in athletes. Sports Med. 1997:24(3):205-20.

5. Burkhart SS, Ricchetti ET, Levine WN, Galatz LM. Challenges and controversies in treating massive rotator cuff tears. Instr Course Lect. 2016; 65:93-108.

6. Senekovic $V$, Poberaj B, Kovacic $L$, et al. The biodegradable spacer as a novel treatment modality for massive rotator cuff tears: a prospective study with 5-year follow-up. Arch Orthop Trauma Surg. 2017;137(1):95-103. https://doi.org/10.1007/s00402-016-2603-9.

7. Abrams JS. Arthroscopic approach to massive rotator cuff tears. Instr Course Lect. 2006:55:59-66.

8. Delaney RA, Lin A, Warner JJ. Nonarthroplasty options for the management of massive and irreparable rotator cuff tears. Clin Sports Med. 2012;31(4): 727-48. https://doi.org/10.1016/j.csm.2012.07.008.

9. Fuchs B, Weishaupt D, Zanetti M, Hodler J, Gerber C. Fatty degeneration of the muscles of the rotator cuff: assessment by computed tomography versus magnetic resonance imaging. J Shoulder Elb Surg. 1999:8:599-605.

10. Valenti P. Joint-preserving treatment options for irreparable rotator cuff tears. Orthopade. 2018;47(2):103-12. https://doi.org/10.1007/s00132-017-3516-1.

11. Berth A, Neumann W, Awiszus F, Pap G. Massive rotator cuff tears: functional outcome after debridement or arthroscopic partial repair. J Orthop Traumatol. 2010;11(1):13-20. https://doi.org/10.1007/s10195-0100084-0

12. Cuff DJ, Pupello DR, Santoni BG. Partial rotator cuff repair and biceps tenotomy for the treatment of patients with massive cuff tears and retained overhead elevation: midterm outcomes with a minimum 5 years of followup. J Shoulder Elb Surg. 2016;25(11):1803-9. https://doi.org/10.1016/j.jse. 2016.04.001

13. Franceschi F, Papalia R, Vasta S, Leonardi F, Maffulli N, Denaro V. Surgical management of irreparable rotator cuff tears. Knee Surg Sports Traumatol Arthrosc. 2015:23(2):494-501. https://doi.org/10.1007/s00167-012-2317-7.

14. Godenèche A, Freychet B, Lanzetti RM, Clechet J, Carrillon Y, Saffarini M. Should massive rotator cuff tears be reconstructed even when only partially repairable? Knee Surg Sports Traumatol Arthrosc. 2017;25(7):2164-73. https://doi.org/10.1007/s00167-016-4105-2.

15. Heuberer PR, Kölblinger R, Buchleitner $S$, et al. Arthroscopic management of massive rotator cuff tears: an evaluation of debridement, complete, and partial repair with and without force couple restoration. Knee Surg Sports Traumatol Arthrosc. 2016;24(12):3828-37.

16. Holtby R, Razmjou H. Relationship between clinical and surgical findings and reparability of large and massive rotator cuff tears: a longitudinal study. BMC Musculoskelet Disord. 2014;15:180. https://doi.org/10.1186/1471-247415-180.

17. lagulli ND, Field LD, Hobgood ER, Ramsey JR, Savoie FH 3rd. Comparison of partial versus complete arthroscopic repair of massive rotator cuff tears. Am J Sports Med. 2012:40(5):1022-6. https://doi.org/10.1177/0363546512438763.

18. Kim SJ, Lee IS, Kim SH, Lee WY, Chun YM. Arthroscopic partial repair of irreparable large to massive rotator cuff tears. Arthroscopy. 2012;28(6):761-8. https://doi.org/10.1016/j.arthro.2011.11.018. 
19. Mori D, Funakoshi N, Yamashita F. Arthroscopic surgery of irreparable large or massive rotator cuff tears with low-grade fatty degeneration of the infraspinatus: patch autograft procedure versus partial repair procedure. Arthroscopy. 2013:29(12):1911-21. https://doi.org/10.1016/j.arthro.2013.08.032.

20. Paribelli G, Boschi S, Randelli P, Compagnoni R, Leonardi F, Cassarino AM. Clinical outcome of latissimus dorsi tendon transfer and partial cuff repair in irreparable postero-superior rotator cuff tear. Musculoskelet Surg. 2015;99(2): 127-32. https://doi.org/10.1007/s12306-015-0353-4.

21. Shon MS, Koh KH, Lim TK, et al. Arthroscopic partial repair of irreparable rotator cuff tears: preoperative factors associated with outcome deterioration over 2 years. Am J Sports Med. 2015;43(8):1965-75. https://doi. org/10.1177/0363546515585122.

22. Viswanathan M, Ansari MT, Berkman ND, et al. Assessing the risk of bias of individual studies in systematic reviews of health care interventions. Methods guide for effectiveness and comparative effectiveness reviews [internet]. Rockville (MD): Agency for Healthcare Research and Quality (US); 2008-2012 Mar 8.

23. Sambandam SN, Gul A, Priyanka P. Analysis of methodological deficiencies of studies reporting surgical outcome following cemented total-joint arthroplasty of trapezio-metacarpal joint of the thumb. Int Orthop. 2007; 31(5):639-45 Epub 2006 Sep 23.

24. Hamada K, Fukuda H, Mikasa M, Kobayashi Y. Roentgenographic findings in massive rotator cuff tears a long-term observation. Clin Orthop Relat Res. 1990:254:92-6.

25. Burkhart SS, Nottage WM, Ogilvie-Harris DJ, et al. Partial repair of irreparable rotator cuff tears. Arthroscopy. 1994;10:363-70.

26. Lubiatowski P, Kaczmarek P, Dzianach M, et al. Clinical and biomechanical performance of patients with failed rotator cuff repair. Int Orthop. 2013; 37(12):2395-401. https://doi.org/10.1007/s00264-013-2024-0.

27. Mallon WJ, Wilson RJ, Basamania CJ. The association of suprascapular neuropathy with massive rotator cuff tears: a preliminary report. J Shoulder Elb Surg. 2006;15:395-8.

28. Itoi $\mathrm{E}$, Minagawa $\mathrm{H}$, Sato $\mathrm{T}$, et al. Isokinetic strength after tears of the supraspinatus tendon. J Bone Joint Surg Br. 1997;79:77-82.

29. Lee KW, Moon KH, Ma CH, Lee GS, Yang DS, Choy WS. Clinical and radiologic outcomes after medializing and not medializing rotator cuff tendon attachment site on chronic retracted rotator cuff tears. Arthroscopy. 2018. https://doi.org/10.1016/j.arthro.2018.03.015.

30. Burkhart SS, Athanasiou KA, Wirth MA. Margin convergence: a method of reducing strain in massive rotator cuff tears. Arthroscopy. 1996;12(3):335-8.

\section{Submit your manuscript to a SpringerOpen ${ }^{\circ}$ journal and benefit from:}

- Convenient online submission

- Rigorous peer review

- Open access: articles freely available online

- High visibility within the field

- Retaining the copyright to your article

Submit your next manuscript at $\boldsymbol{\nabla}$ springeropen.com 